\title{
High-level, erythroid-specific expression of the human $\alpha$-globin gene in transgenic mice and the production of human hemoglobin in murine erythrocytes
}

\author{
Olivia Hanscombe, Miguel Vidal, Jaspal Kaeda, ${ }^{1}$ Lucio Luzzatto, ${ }^{1}$ David R. Greaves, \\ and Frank Grosveld
}

Laboratory of Gene Structure and Expression, National Institute for Medical Research, The Ridgeway, Mill Hill, London NW7 1AA UK; ${ }^{1}$ Department of Haematology, Royal Postgraduate Medical School, Hammersmith Hospital, London W12 OHS UK

\begin{abstract}
Using the dominant control region (DCR) sequences that flank the $\beta$-globin gene locus, we have been able to achieve high-level expression of the human $\alpha$-globin gene in transgenic mice. Expression in fetal liver and blood is copy number dependent and at levels comparable to that of the endogenous mouse $\alpha$-globin genes. Transgenic fetuses with high-copy numbers of the transgene suffer severe anemia and die before birth. Using a construct with both the human $\alpha$ - and $\beta$-globin genes and the $\beta$-globin DCR, live mice with low-copy numbers were obtained. Both human globin genes are expressed at high levels in adult red cells to give human hemoglobin $\mathrm{HbA}$ in amounts equal to or greater than endogenous mouse hemoglobin. Expression of $\mathrm{HbA}$ in murine red cells is not accompanied by any increase in mean corpuscular volume (MCV) or mean corpuscular hemoglobin concentration (MCHC). However, these transgenic mice tend to have an increased number of reticulocytes in peripheral blood, consistent with some degree of hemolysis. Metabolic labeling experiments showed balanced mouse globin synthesis, but imbalanced human globin synthesis, with an $\alpha / \beta$ biosynthetic ratio of $\sim 0.6$. Thus, these mice have mild anemia. These results are discussed with relation to the coordinate regulation of $\alpha$ - and $\beta$-globin synthesis in erythroid tissues.
\end{abstract}

[Key Words: $\alpha$-Thalassemia; globin gene regulation; transgenic mice]

Received April 28, 1989; revised version accepted July 26, 1989.

Hemoglobin is the oxygen-carrying molecule of red blood cells and comprises up to $90 \%$ of total cellular protein. Adult human hemoglobin A (HbA) consists of two $\alpha$ - and two $\beta$-globin chains, each complexed with a heme molecule. The human $\alpha$-like globin genes are clustered on chromosome 16 and comprise the embryonic $\zeta$ gene, two adult $\alpha$-globin genes, $\alpha_{1}$ and $\alpha_{2}$ and the recently described $\theta$-globin gene, for which low levels of RNA have been detected in erythroid cell lines but for which no function has yet been ascertained (Marks et al. 1986; Leung et al. 1987; Shaw et al. 1987). The human $\beta$-like globin genes are clustered on chromosome 11 and comprise the embryonic $\epsilon$, the two fetal $\gamma$-genes ${ }^{\mathrm{G}} \gamma$ and ${ }^{\mathrm{A}} \gamma$, and the adult $\delta$ - and $\beta$-globin gene (Maniatis et al. 1981).

Genetically inherited defects in both $\alpha$ and $\beta$-globin gene clusters are common and give a number of hemoglobinopathies, including $\alpha$ - and $\beta$-thalassemias, which are characterized by decreased synthesis of either $\alpha$ - or $\beta$-globin chains, with an imbalance in the $\beta / \alpha$ biosynthetic ratio (Weatherall and Clegg 1981). There is a wide range of clinical severity, depending on the extent of globin deficit and on the relative rates of $\alpha$ - and $\beta$-globin chain synthesis. The most severe $\left(\beta^{\circ}\right)$ thalassemias, in which no $\beta$-globin chains are produced at all, are characterized in the homozygous state by much decreased mean corpuscular volume (MCV) and mean corpuscular hemoglobin $(\mathrm{MCH})$, by the appearance of immature red cell precursors in peripheral blood, and by marked ineffective erythropoiesis. Treatment of $\beta^{\circ}$ thalassemia is by a regular high blood transfusion regime and intensive iron chelation. Structural mutations of either the $\alpha$ - or the $\beta$-globin gene cause a variety of hemoglobinopathies, the most severe and most common of which is sickle cell anemia. A single amino acid change at codon 6 allows polymerization of deoxygenated hemoglobin tetramers, causing a change in red cell morphology that can lead to blockages in microcapillaries and cause tissue damage (Serjeant 1985). There is presently no good animal model system in which to study sickle cell disease.

A series of erythroid-specific DNase I hypersensitive sites border the human $\beta$-globin locus on chromosome 11 (Tuan et al. 1985; Forrester et al. 1987; Grosveld et al. 1987). When these sequences are included in a human $\beta$-globin construct and are present in transgenic mice or 
mouse erythroleukemic cells, each copy of the human $\beta$-globin gene is expressed as efficiently as the endogenous mouse $\beta$-globin genes (Grosveld et al. 1987; Blom van Assendelft et al. 1989; Talbot et al. 1989). This expression is independent of the position of integration of the transgene and exhibits copy-number dependence. We have been unable to obtain even very low-level expression of the human $\alpha$ - (and $\theta-$ ) globin gene in transgenic mice (this paper), using constructs containing just human $\alpha$-globin gene fragments. However, by placing the $\beta$-globin dominant control region (DCR) next to the human $\alpha$ - and $\theta$-globin genes, we can obtain position-independent expression of the human $\alpha$-globin gene at levels, per gene copy, at least as high as that of the endogenous mouse $\alpha$-globin genes. These data contrast with the results of Ryan et al. (1989), who used an incomplete $\beta$-globin DCR to obtain human $\alpha$-globin gene expression in transgenic mice, but this was not copy dependent or independent of the site of transgene integration. Furthermore, we have been able to detect expression of the introduced human $\theta$-globin gene, albeit at much lower levels than that observed for the human $\alpha$ globin transgene. Using a construct with both the human $\alpha$ - and human $\beta$-globin genes and the $\beta$-globin DCR, we derived transgenic mouse lines expressing more human hemoglobin, $\mathrm{HbA}$, than mouse hemoglobin in adult red cells, demonstrating the feasibility of using transgenic mice for generating animal models of human hemoglobinopathies.

\section{Results}

Transgenic embryos expressing the human $\alpha$-globin gene

Previous attempts to obtain transgenic mice expressing the human $\alpha$-globin gene had proved unsuccessful (unpubl. and see below). Therefore, we investigated the effect of adding the $\beta$-globin locus-dominant control region to the human $\alpha$-globin gene. A 7-kb BglII-Asp718 fragment encompassing the human $\alpha_{1}$ gene and the $\theta$ globin gene was cloned between the ClaI and Asp718 sites of the $\beta$-minilocus cosmid (Grosveld et al. 1987), and a $41-\mathrm{kb}$ Sall fragment was prepared for injection into fertilized mouse eggs (1301, Fig. 1). Nine transgenic fetuses were obtained, and the copy number of the transgene was determined by Southern blot analysis of placental DNA (Fig. 2A). The transgene copy number was estimated by comparison of hybridization signals obtained with a human $\alpha$-globin gene probe, which detects a $5.6-\mathrm{kb}$ fragment in EcoRI-digested mouse placental DNA with the hybridization signal obtained with the human placental DNA (Fig. 2A, lane $\mathrm{Hu}$ ) and plasmid dilutions (Fig. 2A, lanes $10 \times$ and $1 \times$ ). Signals were corrected for DNA loading by comparison of the hybridization signals for the single-copy mouse Thy-1 gene. All nine transgenic mice contained unrearranged copies of the $\alpha \theta$ fragment, including the four 5' DNase I hypersensitive sites (Fig. 2B and data not shown). Southern blot analysis of placental, liver, and body DNA for each embryo showed that four of the nine were mosaics, as transgene copy number was different for each tissue (data not shown). The 12.5-day fetuses with the highest copy number of the $\alpha \theta$ construct that were not mosaic $\{92,87$, and 81$)$ were anemic with very small fetal livers (Fig. 3). This is very similar to the fetal anemia obtained with the $\beta$-globin gene in the minilocus /Grosveld et al. 1987; Talbot et al. 1989).

RNA was prepared from whole embryo and used in a S1 nuclease protection analysis of human $\alpha$-globin expression. The S1 analysis of embryo RNAs shown in Figure 2C demonstrates that each human $\alpha$-globin gene is expressed in direct relation to $\alpha$-gene copy number at a level, per gene copy, at least as high as that of each of the endogenous mouse $\alpha$-globin genes. For example, mice 93 and 71 , which carry a single copy of the $\alpha \theta$ cosmid, give an S1-protected fragment of equal intensity to that of the mouse $\alpha$-globin mRNA. The embryo RNA of the anemic mouse 92, which carries eight copies of the $\alpha \theta$ cosmid, shows a high level of human $\alpha$-globin mRNA and no detectable mouse $\alpha$-globin mRNA (Fig. 2C; Table 1). Detectable levels of human $\alpha$-globin expression in transgenic animals is only observed when the $\beta$-globin locus DCR is present in the construct; mice 33 and 36 , which carry only the 7-kb Asp718-ClaI fragment, do not express the human $\alpha$-globin gene (Fig. 2). Similar results were obtained from the analysis of fetal liver and blood RNAs of nonanemic animals (data not shown).

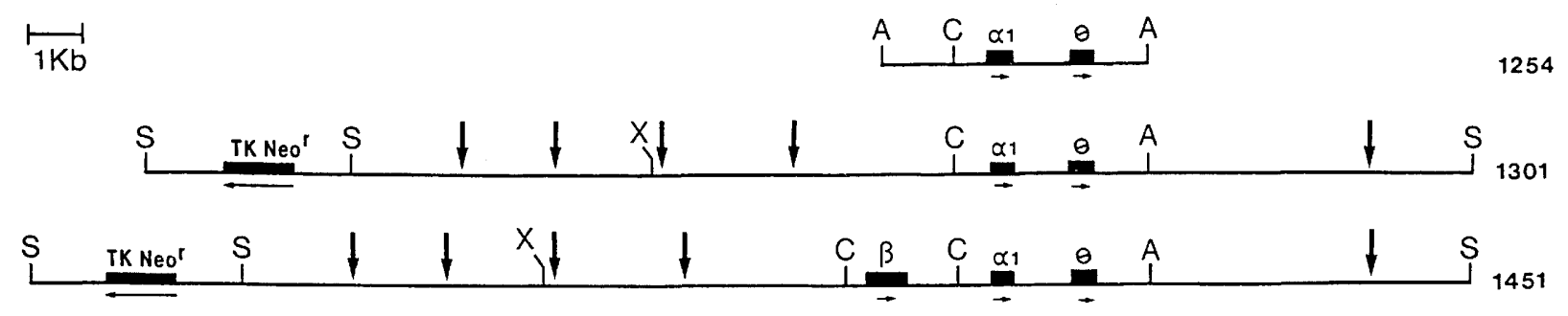

Figure 1. Constructs used to generate transgenic mice. Construct 1254 has a $7-\mathrm{kb} B g / \mathrm{II}-A s p 718$ fragment of the human $\alpha$-globin locus cloned between $\mathrm{BamHI}$ and $\mathrm{ClaI}$ sites of the vector pUC/Cla (Grosveld et al. 1987). The insert was excised with $A s p 718$ and $\mathrm{ClaI}$ for microinjection. Construct 1301 has the ClaI-Asp718 fragment of construct 1254 cloned between the ClaI and Asp718 sites of the $\beta$-minilocus cosmid (Grosveld et al. 1987). A ClaI-linkered 4-kb SphI-BglII human $\beta$-globin gene fragment was inserted into the unique ClaI site of 1301 to give construct 1451. Vertical arrows indicate positions of erythroid-specific DNase I hypersensitive sites; horizontal arrows indicate transcriptional orientation of the globin and $t k$-neor genes. (A) Asp 718 ; (C) ClaI; (S) SalI; (X) XhoI. 
Hanscombe et al.
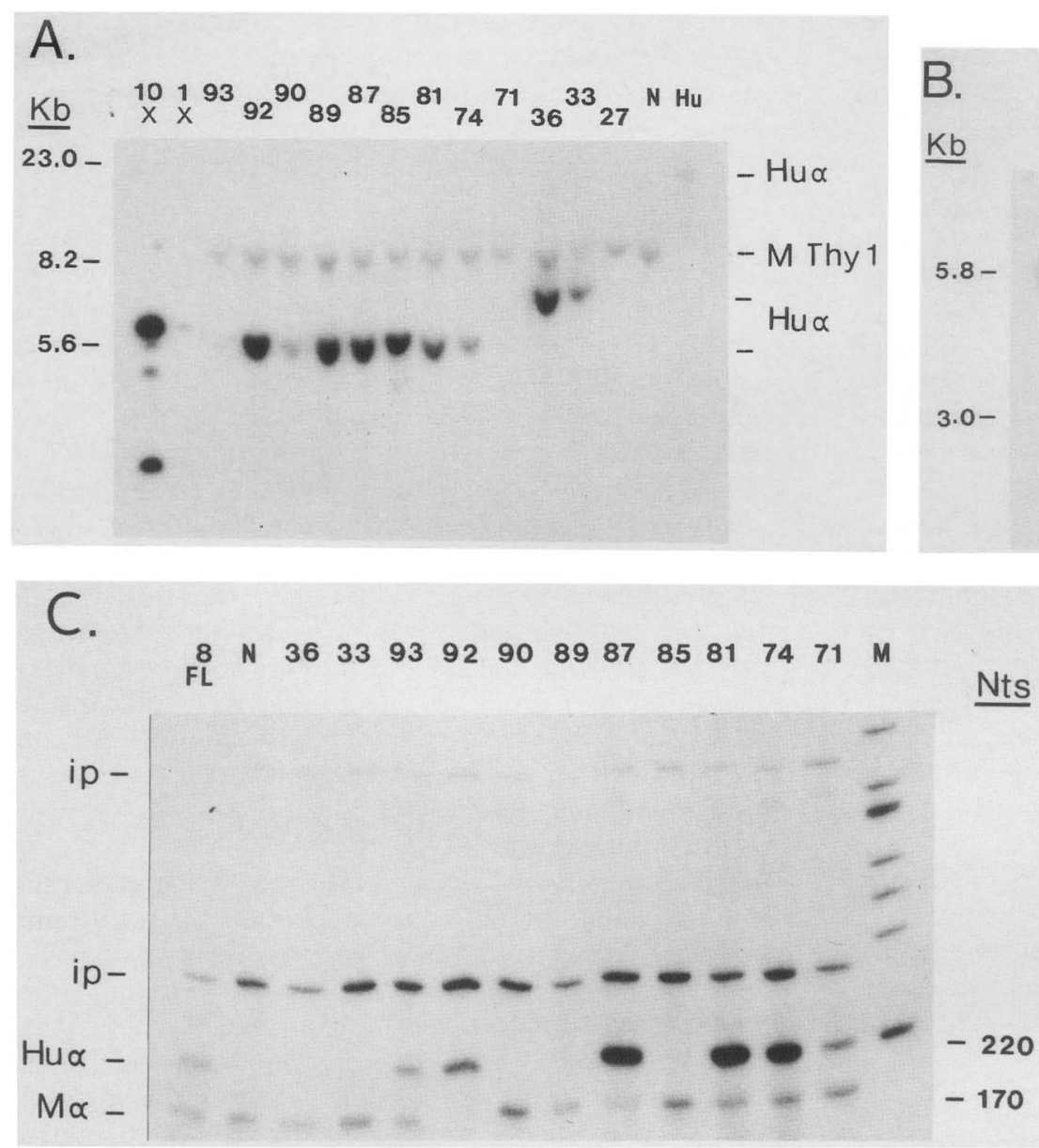
Whole-embryo RNA $(1 \mu \mathrm{g})$ was hybridized with a mixture of mouse $\alpha$ - and human $\alpha$-specific S1 probes (sp. act. ratio $1: 2)$. The S2 digestion products were resolved on a $6 \%$ sequencing gel, and the positions of protected fragments and input probes (ip) are marked. Nontransgenic embryo RNA ( $N$ ) was used as negative control; fetal liver RNA ( $250 \mathrm{ng}$ ) of transgenic embryo 8 was used as positive control (FL). Sizes indicated are in nucleotides (Nts).

Figure 3. High-copy-number $\alpha \theta$ transgenic embryos die of a severe anemia. Transgenic embryo 81 (right) is shown alongside a nontransgenic littermate dissected from the same foster mother 12.5 days after transfer of microinjected eggs. Note the very small fetal liver and extreme pallor compared to the normal embryo.
Figure 2. Copy number and expression analysis of $\alpha \theta$ transgenic embryos. (A) Placental DNA samples $(10 \mu \mathrm{g})$ of 13.5 -day transgenic embryos were digested with EcoRI and transferred to nitrocellulose after electrophoresis. The filter was hybridized with a mixture of mouse Thy-1.2 and human $\alpha$-globin probes and washed to a final stringency of $0.1 \times$ SSC, $0.1 \%$ SDS. Plasmid DNA $(10 \times$ and $1 \times)$ diluted to give a signal equivalent to 10 and 1 copies, respectively, of the transgene in $10 \mu \mathrm{g}$ of genomic DNA. EcoRI-digested nontransgenic mouse DNA $(10 \mu \mathrm{g})$ and human placental DNA (10 $\mu \mathrm{g}$ ) were loaded in lanes $N$ and $H u$. (B) The filter used in $A$ was stripped and rehybridized with a 3.3-kb EcoRI probe that encompasses the 5' end of the SalI fragment of 1301 used for microinjection. $(C)$ fragments and input probes (ip) are marked.
of transgenic embryo 8 was used as positive

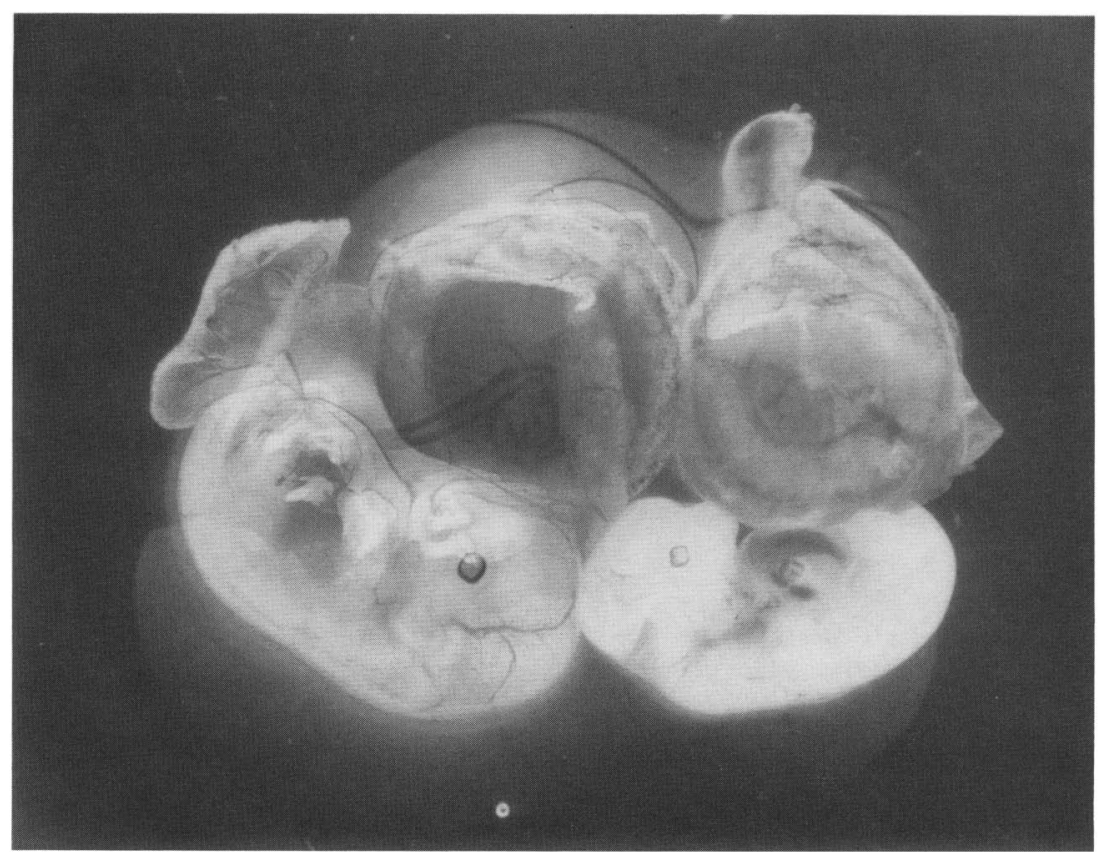


Table 1. Copy-number and expression analysis of $\alpha \theta$ transgenic embryos

\begin{tabular}{lcccc}
\hline Mouse $^{\mathrm{a}}$ & $\begin{array}{l}\text { Embryo } \\
\text { age }^{\mathrm{b}}\end{array}$ & $\begin{array}{l}\text { Copy } \\
\text { number }\end{array}$ & $\alpha \mathrm{H} / \alpha \mathrm{M}^{\mathrm{d}}$ & $\begin{array}{c}\alpha \mathrm{H} / \alpha \mathrm{M} / \alpha \mathrm{H} \\
\text { gene copy }\end{array}$ \\
\hline 93 & 12.5 & 1 & 0.57 & 0.57 \\
$92^{+}$ & 12.5 & 8 & $\mathrm{ND}$ & $\mathrm{ND}$ \\
90 & 12.5 & $\mathrm{M}$ & - & - \\
89 & 12.5 & $\mathrm{M}$ & - & - \\
$87^{+}$ & 12.5 & 8 & $>50+$ & $>6.00$ \\
85 & 13.5 & $\mathrm{M}$ & - & - \\
$81^{+}$ & 13.5 & 8 & 6.2 & 0.77 \\
74 (del) & 13.5 & 3 & 5.3 & 1.76 \\
71 & 13.5 & 1 & 0.55 & 0.55 \\
\hline
\end{tabular}

${ }^{2}$ Embryos marked + were anemic (see Fig. 3). There was not enough mouse $\alpha$ signal to give a meaningful ratio. (del) Deletion in mouse 74 , which appears to have three copies of the $\alpha$ gene but more than three copies of DCR sequences (Fig. 2A and B).

bEmbryos were dissected 12.5 or 13.5 days after transfer of injected eggs.

cTransgene copy number was determined by densitometry of a range of exposures of the Southern blots shown in Fig. 2, A and B. (M) Mosacism.

dThe ratio of human $\alpha$ - to mouse $\alpha$-globin mRNA $(\alpha \mathrm{H} / \alpha \mathrm{M})$ was calculated by densitometric scanning of $\mathrm{S} 1$ analyses of embryo, blood, and fetal liver RNAs (Fig. 2C; data not shown), correcting for differences in specific activities. Four additional transgenic 12.5-day embryos were obtained, however, insufficient DNA was available to check rigorously for mosaicism and they were therefore not included in this analysis. Fetal liver RNA of one of these mice (FL 8) was used as an internal standard for $\alpha$-globin S1 analysis.

\section{$\alpha \beta$ Transgenic mice}

We observed previously that transgenic fetuses with high-copy numbers of the human $\beta$-globin gene and the $\beta$-globin DCR die in utero and displayed a thalassemialike anemia similar to that illustrated in Figure 3 (Grosveld et al. 1987; Talbot et al. 1989). To overcome the lethal anemia and investigate the possibility of establishing animal disease models, we cloned a single copy of human $\beta$-globin gene into the ClaI site of the $\alpha \theta$ cosmid (Fig. 1). A 45-kb Sall fragment was injected into $\mathrm{F}_{2}$ fertilized mouse eggs, and after transfer to pseudopregnant foster mothers, 26 live mice were obtained. Five mice were identified as being transgenics by Southern blot analysis of tail biopsy DNA with a human $\alpha$-globin gene probe (data not shown). Four transgenic lines were established by breeding with nontransgenic $\mathrm{F}_{1}$ CBA $\times$ C57BL animals (Table 2). Southern blot analysis with probes spanning the $45-\mathrm{kb}$ Sall fragment showed that two mice, 14 and 39 , had sustained deletions of DCR sequences (Fig. 4A and B; data not shown). Offspring of founder mouse 10 have five intact copies of the $\beta \alpha \theta$ fragment, offspring of mouse 31 have two copies, and founder mouse 15 appears to have six copies; this mouse did not give transgenic offspring, and we concluded that mouse 15 is a mosaic. Moreover, part of the $\beta$-globin genes of mouse 15 have undergone a deletion (Fig. 4B, inset).
RNA was prepared from blood, spleen, and thymus of transgenic mice, and a S1 nuclease protection assay was used to determine the level of human $\alpha$ - and $\beta$-globin expression (Fig. 4C, D, and E). The steady-state level of human $\beta$-globin mRNA in mouse 10 blood and spleen RNAs is 2.5 times that of the endogenous mouse $\beta$ globin mRNA; there are approximately equal amounts of human and mouse $\beta$-globin mRNAs in mouse 31 (Fig. 4D). The level of human $\alpha$-globin mRNA is half that of the human $\beta$-globin mRNA (Fig. $4 \mathrm{C}$ ). Erythroid specificity of this expression is shown by the analysis of thymus RNA. The human $\beta$-globin signal seen is $1 \%$ that of spleen and is due to blood contamination of thymus tissue, as shown by the presence of the mouse $\beta^{\text {mai }}$ signal (Fig. 4E). Using a 3 '-end probe for the human $\theta$-globin gene, we were able to detect low-level expression of the $\theta$ transgene in spleen RNA of mouse 10 (Fig. $4 \mathrm{~F}$ ), but the levels of expression are at least 100 times lower than that of the human $\alpha$-globin gene.

\section{$\alpha \beta$ Transgenic mice expression human hemoglobin}

Having shown high-level, erythroid-specific expression of both human $\alpha$ - and $\beta$-globin genes in adult mice, we looked for the expression of $\mathrm{HbA}\left(\alpha_{2} \beta_{2}\right)$, in transgenic mouse blood. Mouse hemoglobin and human hemoglobin can be resolved by isoelectric focusing under native conditions (Fig. 5). Mice 15 and 31 have about equal amounts of human and mouse hemoglobin, whereas mouse 10 has three to four times more human hemoglobin than mouse hemoglobin. Mice 39 and 14, which have deletions in the DCR sequences, have no detectable HbA consistent with the RNA analysis of Figure 4.

\section{Hematological analysis of $\alpha \beta$ transgenic mice}

The $\alpha \beta$ transgenic mice had hemoglobin levels within the normal range (Table 3); however, they tended to have a higher reticulocyte count than the controls and some morphological abnormalities in the way of poiki-

Table 2. Copy number and expression analysis of $\alpha \beta$ transgenic mice

\begin{tabular}{|c|c|c|c|}
\hline Mouse & $\begin{array}{l}\text { Copy } \\
\text { number }\end{array}$ & $\mathrm{H} \alpha / \mathrm{M} \alpha \mathrm{RNA}$ & $\mathrm{H} \beta / \mathrm{M} \beta \mathrm{RNA}$ \\
\hline 10 & 5 & 1.9 & 2.6 \\
\hline 14 & $\begin{array}{l}0.76 \\
\text { (mosaic) }\end{array}$ & - & - \\
\hline 15 & $\begin{array}{l}6 \text { (partial } \\
\beta \text { deletion) }\end{array}$ & $\begin{array}{l}1.8 \\
\quad(5 \text { copies })\end{array}$ & $\begin{array}{l}1.3 \\
(2 \text { copies })\end{array}$ \\
\hline 31 & 2 & 0.7 & 1.0 \\
\hline 39 & 3 (deletion) & - & - \\
\hline
\end{tabular}

Adult transgenic mice were sacrificed, and transgene copy number was determined by Southern blot analysis and densitometry (Fig. 4A and B). The ratios of human and mouse $\alpha$ - and $\beta$-globin mRNAs were determined by densitometric scanning of $\mathrm{S} 1$ nuclease analyses and corrected for specific activity differences (Fig. 4C and D). 
Hanscombe et al.

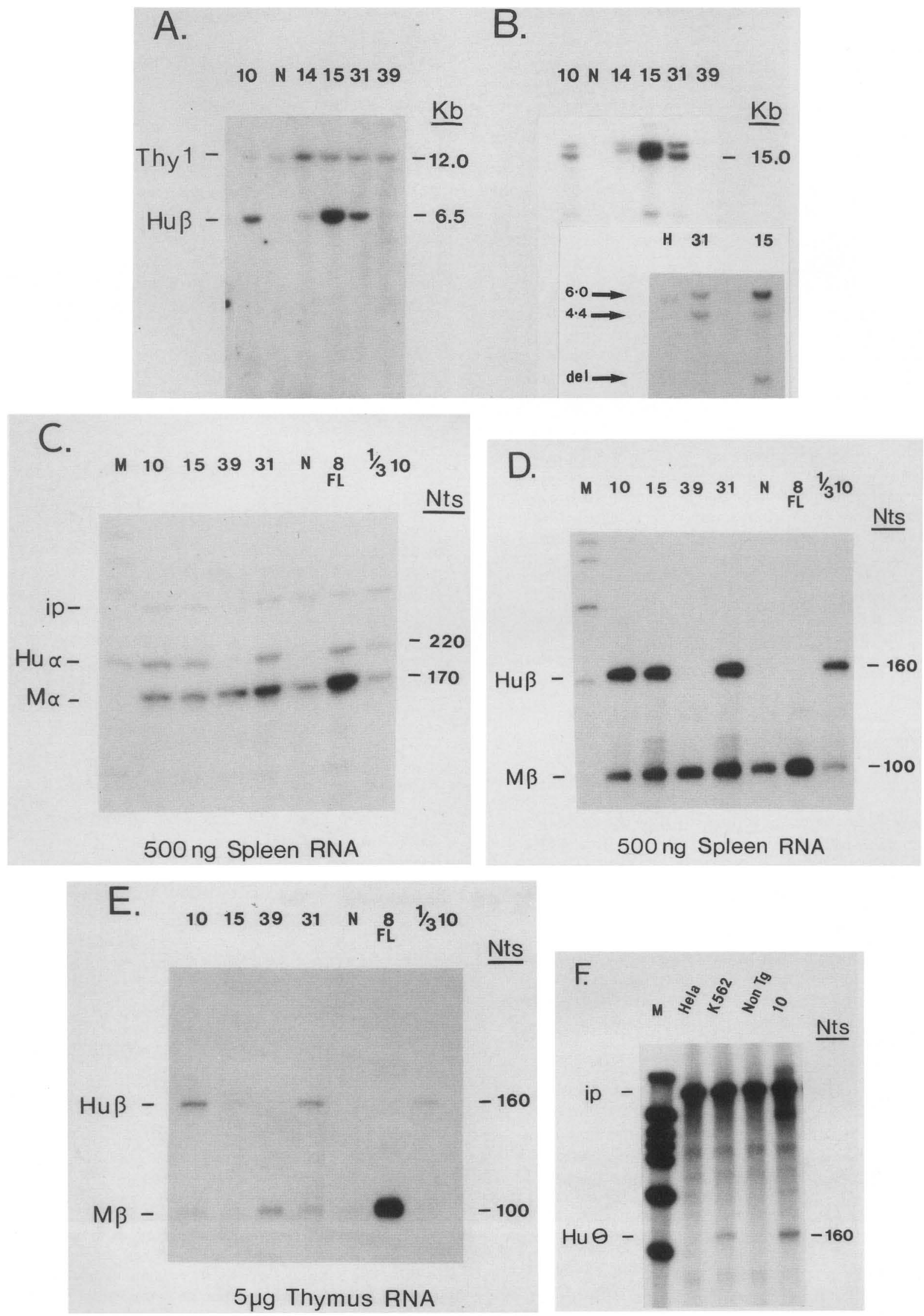

Figure 4. (See legend on following page.) 


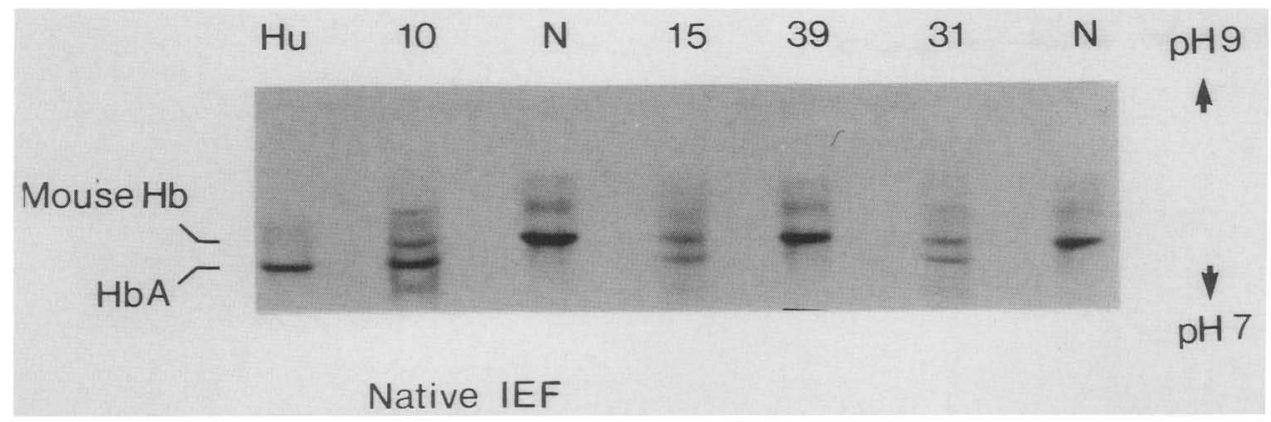

Figure 5. Electrophoretic analysis of hemoglobins in transgenic mouse blood. Human $(\mathrm{Hu})$, nontransgenic $(\mathrm{N})$, and $\alpha \beta$ transgenic mouse blood samples were lysed in $0.25 \mathrm{M}$ sucrose and $1 \%$ Trasylol (Bayer), cleared by centrifugation, and normalized by $\mathrm{OD}_{415}$. Two $\mathrm{OD}_{415}$ units of cell lysate were applied to a horizontal isoelectric focusing gel. The gel was run for $2 \mathrm{hr}$ at $600 \mathrm{~V}$ before photography. Hemoglobin species were visualized without staining.

locytosis and polychromasia (Fig. 6). These findings suggest a mild anemia, not immediately apparent from the $\mathrm{MHC} / \mathrm{MCV}$ data, which is similar to the situation in human $\alpha$-thalassemia due to a triplication of the $\alpha$ globin gene (Weatherall and Clegg 1981). This is different from a classical thalassemia, which is characterized by the absence of genes rather than an abundance of genes.

Because only tetrameric hemoglobin molecules are stable, the proportions of various hemoglobin components found in blood (Fig. 5) may not necessarily reflect the rates of synthesis of the respective globin chains. To measure globin biosynthetic ratios directly, we carried out metabolic labeling experiments with $\left[{ }^{3} \mathrm{H}\right]$ leucine in peripheral blood reticulocytes. Globin chains purified after a 2 -hr incubation were fractionated by carboxymethyl cellulose column chromatography in $8 \mathrm{M}$ urea (Clegg et al. 1968). With blood of mouse 10, four discrete peaks of radioactivity are observed, two of which coelute with ${ }^{14} \mathrm{C}$-labeled human globin chains and two of which elute at the same buffer concentration as nontransgenic mouse globin chains (Fig. 7). In two separate experiments on two transgenic siblings, the values for the biosynthetic ratio $\alpha / \beta$ of the mouse globin chains were 0.93 and 1.0 , respectively. In contrast, the values for the biosynthetic ratio $\alpha / \beta$ of the human globin chains were 0.61 and 0.50 , respectively, again in keeping with a mild aneriia. In the same two experiments the values of the ratio of total human to total mouse globins synthesized were 1.51 and 1.61, respectively, in agreement with the steady-state mRNA levels.

\section{Discussion}

By placing the dominant control region sequences of the $\beta$-globin locus in cis to the human $\alpha$-globin gene, we have been able to obtain transgenic mouse embryos that express high levels of human $\alpha$-globin mRNA. Nonmosaic mice with high human $\alpha$-gene copy numbers die at around day 13 of gestation from a severe anemia. In contrast, transgenic mice carrying both human $\alpha$ - and $\beta$ globin genes and the $\beta$-globin DCR are viable but exhibit a mild $\alpha$-thalassemia.

\section{High-level human $\alpha$-globin expression}

Previous attempts to obtain transgenic mice expressing the human $\alpha$-globin gene have proved unsuccessful (Ryan et al. 1989; this paper). Addition of the four DNase I hypersensitive sites 5 ' of the $\epsilon$ gene and the site downstream of the $\beta$ gene gives copy number-dependent human $\alpha$-globin gene transcription in the erythroid

Figure 4. Copy-number and expression analysis of adult $\alpha \beta$ transgenic mice. (A) Genomic DNA was prepared from livers of indicated $\alpha \beta$ transgenic mice, digested with BamHI, and transferred to nitrocellulose after electrophoresis. The filter was probed with a human $\beta$-globin-specific probe and a mouse Thy-1.2 gene probe and washed to a final stringency of $0.1 \times \mathrm{SSC}$ at $65^{\circ} \mathrm{C}$. (B) The filter of $A$ was stripped of hybridizing DNA by washing in $100 \mathrm{~mm} \mathrm{NaOH}$ and $0.1 \%$ SDS and reprobed with a $0.46-\mathrm{kb}$ EcoRI-BglII probe derived from the $\alpha \theta$ cosmid that detects a $15-\mathrm{kb}$ BamHI fragment and an 18-kb partial BamHI fragment (Blom van Assendelft et al. 1989). (Inset) EcoRI-digested DNA, human placenta $(\mathrm{H})$, and liver DNA of mice 31 and 15, probed with a human $\alpha$ - and a human $\beta$-globin probe. The 6-kb band derives from the human $\alpha$ gene; the 4.4-kb band derives from the human $\beta$-globin gene. Mouse 15 shows a deletion of three copies of the human $\beta$ gene. $(C)$ Spleen RNAs $(500 \mathrm{ng}$ ) of indicated transgenic or nontransgenic $(\mathrm{N})$ mice were hybridized with a mixture of mouse $\alpha$ - and human $\alpha$-specific S1 probes (sp. act. ratio $4: 1$ ). The S1 digestion products were resolved on a $6 \%$ sequencing gel. Fetal liver RNA ( $250 \mathrm{ng}$ ) of transgenic embryo 8 (FL) was used as positive control; one-third the amount of mouse 10 spleen RNA was analyzed to determine whether $S 1$ signals were in the linear range of the assay $(1 / 310) .(D)$ RNAs used in $C$ were hybridized with a mixture of human $\beta$ and mouse $\beta^{\text {mai }}$ S1 probes (sp. act. ratio $\left.1: 1\right)$. (E) Thymus RNAs $(5 \mu \mathrm{g})$ from indicated transgenic and nontransgenic $(\mathrm{N})$ animals were hybridized with the S1 probe mixture used in $D$. Fetal liver of transgenic embryo 8 (250 ng) was used as positive control (8 FL). (F) HeLa cell RNA $(20 \mu \mathrm{g})$, K562 RNA $(20 \mu \mathrm{g})$, and spleen RNA (10 $\mu \mathrm{g})$ from nontransgenic (N) or $\alpha \beta$ transgenic mouse 10 were hybridized to a 5 '-labeled $0.9-\mathrm{kb}$ BamHI fragment derived from the $3^{\prime}$ end of the human $\theta$ gene. The S1 digestion products were anlayzed on a $5 \%$ sequencing gel, and the gel exposed to Kodak XAR-5 film for 4 days, as compared to the 1-hr exposures shown in $C$. (Human $\alpha$ and $\theta$ probes were of equal specific activity.) 
Hanscombe et al.

Table 3. Hematological values in $\alpha \beta$ transgenic mice 10

\begin{tabular}{|c|c|c|c|c|c|c|c|c|c|c|}
\hline & \multicolumn{5}{|c|}{ Controls } & \multicolumn{5}{|c|}{ Transgenic } \\
\hline & $\begin{array}{l}\mathrm{Hb} \\
\{\mathrm{G} / \mathrm{dl})\end{array}$ & $\begin{array}{l}\text { MCV } \\
\text { (fl) }\end{array}$ & $\begin{array}{l}\mathrm{MCH} \\
\text { (pg) }\end{array}$ & $\begin{array}{l}\text { MCHC } \\
\text { (G/dl) }\end{array}$ & $\begin{array}{l}\text { Retic } \\
(\%)\end{array}$ & $\begin{array}{l}\mathrm{Hb} \\
(\mathrm{G} / \mathrm{dl})\end{array}$ & $\begin{array}{l}\mathrm{MCV} \\
\text { (fl) }\end{array}$ & $\begin{array}{l}\mathrm{MCH} \\
\text { (pg) }\end{array}$ & $\begin{array}{l}\mathrm{MCHC} \\
\{\mathrm{G} / \mathrm{dl} \mid\end{array}$ & $\begin{array}{l}\text { Retic } \\
|\%|\end{array}$ \\
\hline \multicolumn{11}{|c|}{ Group I } \\
\hline 1 & ND & 50 & 15 & 31 & ND & ND & 50 & 13 & 27 & ND \\
\hline 2 & ND & 46 & 12 & 26 & ND & ND & 48 & 17 & 35 & ND \\
\hline \multicolumn{11}{|c|}{ Group II } \\
\hline 1 & 13.6 & 54 & 15 & 28 & 6.4 & 13.3 & 55 & 14 & 26 & 14.2 \\
\hline 2 & 12.3 & 56 & 15 & 27 & 14.6 & ND & 54 & 14 & 27 & 9.7 \\
\hline 3 & 13.7 & 57 & 17 & 30 & 4.4 & 11.6 & 54 & 14 & 26 & 14.5 \\
\hline 4 & & & & & & 11.6 & 53 & 14 & 26 & 16.6 \\
\hline 5 & & & & & & 13.2 & 56 & 15 & 26 & 9.5 \\
\hline 6 & & & & & & 12.1 & 61 & 15 & 25 & 20.8 \\
\hline 7 & & & & & & 14.7 & 55 & 17 & 30 & 5.4 \\
\hline 8 & & & & & & 12.8 & 55 & 14 & 26 & 10.0 \\
\hline 9 & & & & & & 10.8 & 53 & 15 & 28 & 12.0 \\
\hline
\end{tabular}

Blood samples from first generation transgenic offspring (group I, mice 1 and 2) or second generation transgenic offspring (group II, mice 1-9) were analyzed for hemoglobin concentration ( $\mathrm{Hb}$ ), mean corpuscular volume (MCV), mean corpuscular hemoglobin (MCH), and mean corpuscular hemoglobin concentration $(\mathrm{MCHC})$, using a Sysmex Electronic blood count system. The percentage of reticulocytes in blood smears was determined (Retic). Control mice in group II were nontransgenic siblings. Group I controls were agematched $F_{1}$ C57BL $\times$ CBA mice. (ND) Not determined. (G/dl) Grams per deciliter; (fl) femptoliter; (pg) picograms.

tissues of transgenic mice. Recently, Ryan et al. (1989) demonstrated erythroid expression of the human $\alpha$ globin gene in transgenic mouse embryos, using a construct with the human $\alpha$ gene and the two DNase I hypersensitive sites proximal to the $\epsilon$ gene. Using such a construct, the investigators observed human $\alpha$-globin expression at levels lower than that of the endogenous mouse $\alpha$-globin genes. In the experiments of Figure 2C, it is clear that nonmosaic mice express the human $\alpha$ gene at levels one- to twofold that of endogenous mouse genes per gene copy. The high-level $\alpha$-globin expression observed using the full $\beta$-globin DCR element in the $a b$ sence of a human $\beta$ gene causes death of the embryo, presumably due to globin chain imbalance, which apparently was not observed with the partial DCR $\alpha$-globin constructs used by Ryan et al. (1989).

The observation that sequences bordering the human $\alpha$-globin locus direct high-level, erythroid expression of the human $\alpha$-globin gene raises the possibility that similar dominant control region sequences may flank the human $\alpha$-globin locus on chromosome 16. Interestingly, a recently reported $\alpha$-thalassemia involves a $70-\mathrm{kb}$ deletion of DNA sequences upstream of the $\alpha_{2}$ - and $\alpha_{1}$-globin genes (Higgs et al. 1987). This situation is very reminiscent of $\gamma \beta$-thalassemia deletions that encompass the $\beta$ globin DCR sequences but leave the $\beta$-globin gene intact (van der Ploeg et al. 1980; Kioussis et al. 1983; Curtin et al. 1985; Taramelli et al. 1986; Driscoll et al. 1989).

\section{Coordinate regulation of human $\alpha$ - and $\beta$-globin synthesis}

Hematological analysis of the live mice obtained with the $\alpha \beta$ construct is consistent with the mice having a mild form of thalassemia. Metabolic labeling experiments revealed that human $\alpha$-globin polypeptide chains were being synthesized at a level approximately half that of the human $\beta$ gene. This is consistent with the steady-state levels of the human globin mRNA assayed in peripheral blood and spleen RNA of these transgenic mice. In human adult erythroid tissues, two functional $\alpha$-globin genes on chromosome 16 are needed to produce as much $\alpha$-globin mRNA as that synthesized by the single-copy adult $\beta$-globin gene on chromosome 11 . When the two human globin genes are transferred to transgenic mice in the presence of the $\beta$-globin DCR sequences, the $\alpha$ and $\beta$ genes seem to reproduce faithfully the relative rates of mRNA and protein synthesis seen in human erythroid cells.

It is noteworthy that the introduction of highly expressed exogenous $\alpha$ - and $\beta$-globin genes in the mouse erythroid cells cause only minimal changes in the $\mathrm{MCH}$ and mean corpuscular hemoglobin concentration (MCHC) of the mature red cells. We do not known whether this is caused by a feedback control exerted on total globin production during erythroid cell maturation, such that the synthesis of human globins causes an underproduction of mouse globins, or a simple ceiling on the total capacity for hemoglobin production.

We have previously presented a model for the mechanism by which the $\beta$-globin gene locus dominant control region sequences exert their effect in erythroid cells (Grosveld et al. 1987). We propose that the $\beta$-globin gene DCR acts to make chromatin throughout the $\alpha / \beta$ transgene fragment more accessible specifically in erythroid cells. Once present in an activated chromatin configuration, the absolute level of transcription is determined by local regulatory elements in the promoters (Talbot et al. 1989). In this regard, it is interesting to note the many differences between the regulation of the human $\alpha$ - and $\beta$-globin gene promoters in cell transfection systems (Treisman et al. 1983; Charnay et al. 1984; Whitelaw et 

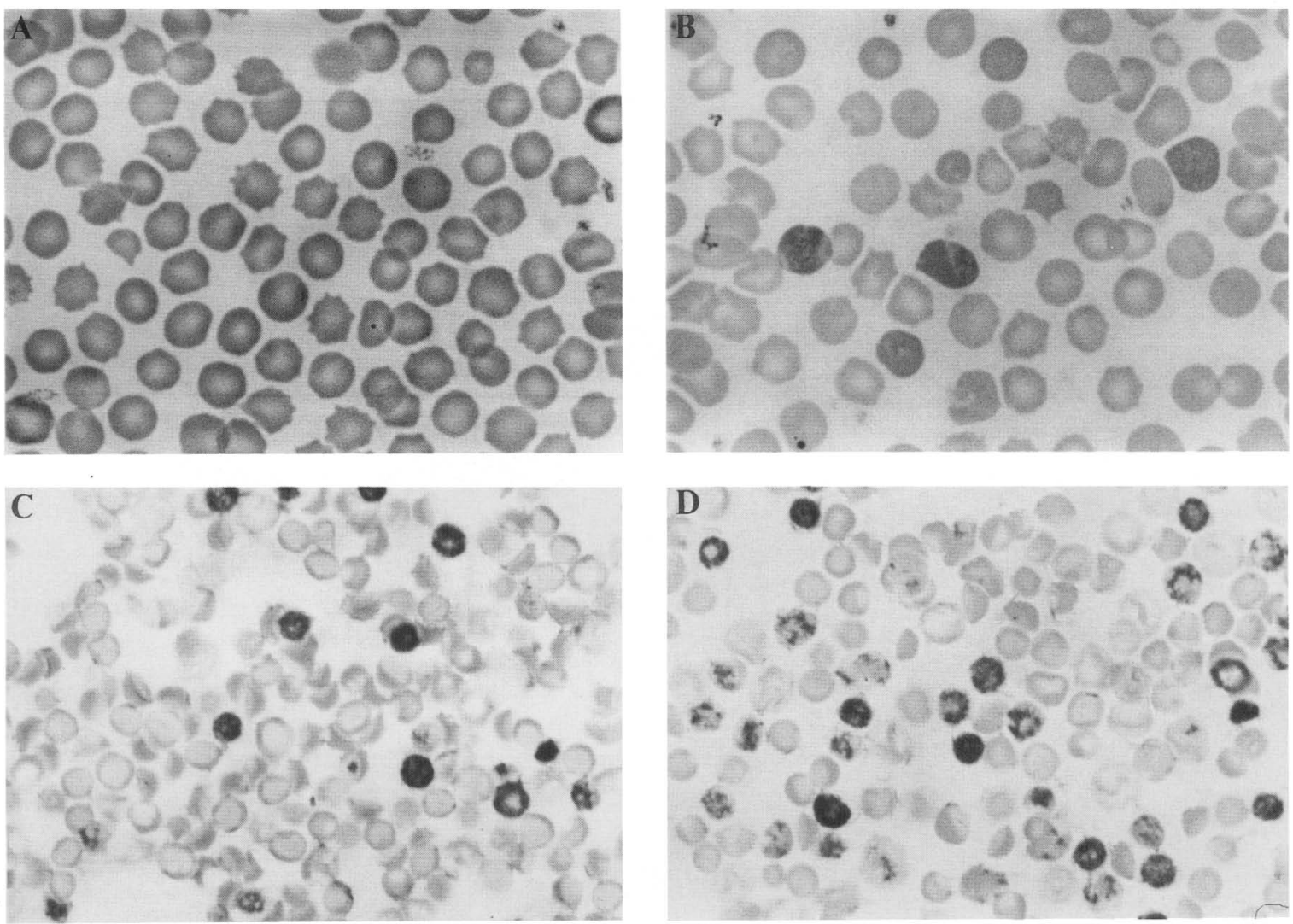

Figure 6. Blood smears of transgenic and nontransgenic mice. Photographs of peripheral blood from a control mouse $(A$ and $C)$ and $\alpha \beta$ transgenic mouse $10(B$ and $D)$. $A$ and $B$ stained with May-Grunwald Giemsa; $C$ and $D$ stained with brilliant Cresyl blue. Compared to the control, the transgenic mouse erythrocytes show marked poikylocytosis and polychromasia and a higher proportion of reticulocytes.

al. 1989), which led to the idea that the $\alpha$ gene may be activated by a single step.

Despite the fact that the $\alpha$-globin gene is transcribed at reasonable rates in many different cell types in transient assays, not even low levels of inappropriate celltype expression is seen in transgenic mice carrying the human $\alpha$-globin gene (Ryan et al. 1989; this paper). Thus, it appears that the $\alpha$-globin gene, itself, is highly tissue specific, because the DCR appears not to suppress transcription in inappropriate tissues (Blom van Assendelft et al. 1989; Greaves et al. 1989). Therefore, we speculate that the $\alpha$ genes may be activated by an, as yet, undefined dominant control region present within the $\alpha$-globin locus on chromosome 16. In an artificial system, the same result is achieved by the action of the $\beta$-globin DCR from chromosome 11 placed in cis.

\section{Mouse models of human hemoglobinopathies}

Thalassemic mice with deletions of adult $\alpha$ - or $\beta$-globin genes have been generated by mutagenesis (Martinell et al. 1981; Skow et al. 1983). Using the human $\beta$-globin DCR and the human $\alpha$ - or $\beta$-globin genes, we have been able to direct such high levels of erythroid-specific human globin expression that transgenic mice develop a fatal imbalance in $\alpha$ - and $\beta$-chain synthesis. We have not yet undertaken a detailed histological examination of these animals, but they are very reminiscent of the human condition hyrops fetalis in which zygotes with all $\alpha$ genes deleted on both chromosomes die before birth (Weatherall and Clegg 1981). In contrast, the live mice that we generated using the $\alpha \beta$ construct have a mild anemia.

It is important to note that our $\alpha$-thalassemic mice were generated by gene addition rather than by gene deletion, attesting to the power of the $\beta$-globin DCR sequences in directing high-level erythroid expression in transgenic mice. Because high levels of functional human hemoglobin can be synthesized in adult transgenic mice, it should be possible to obtain similar results with structural hemoglobin mutant genes introduced into such constructs, for example, $\beta^{\text {s. In this re- }}$ gard, a key observation is that expression of human hemoglobin in mouse erythrocytes is not accompanied by an increased MCV or MCHC, both parameters that critically affect the rate of sickle cell hemoglobin polymerization in vivo (Schechter et al. 1987). It appears that the erythroid cell tends to underproduce mouse hemoglobin in this situation. The fact that we see a relative shortage of human $\alpha$-globin produced suggests that we may also be able to investigate the association with 


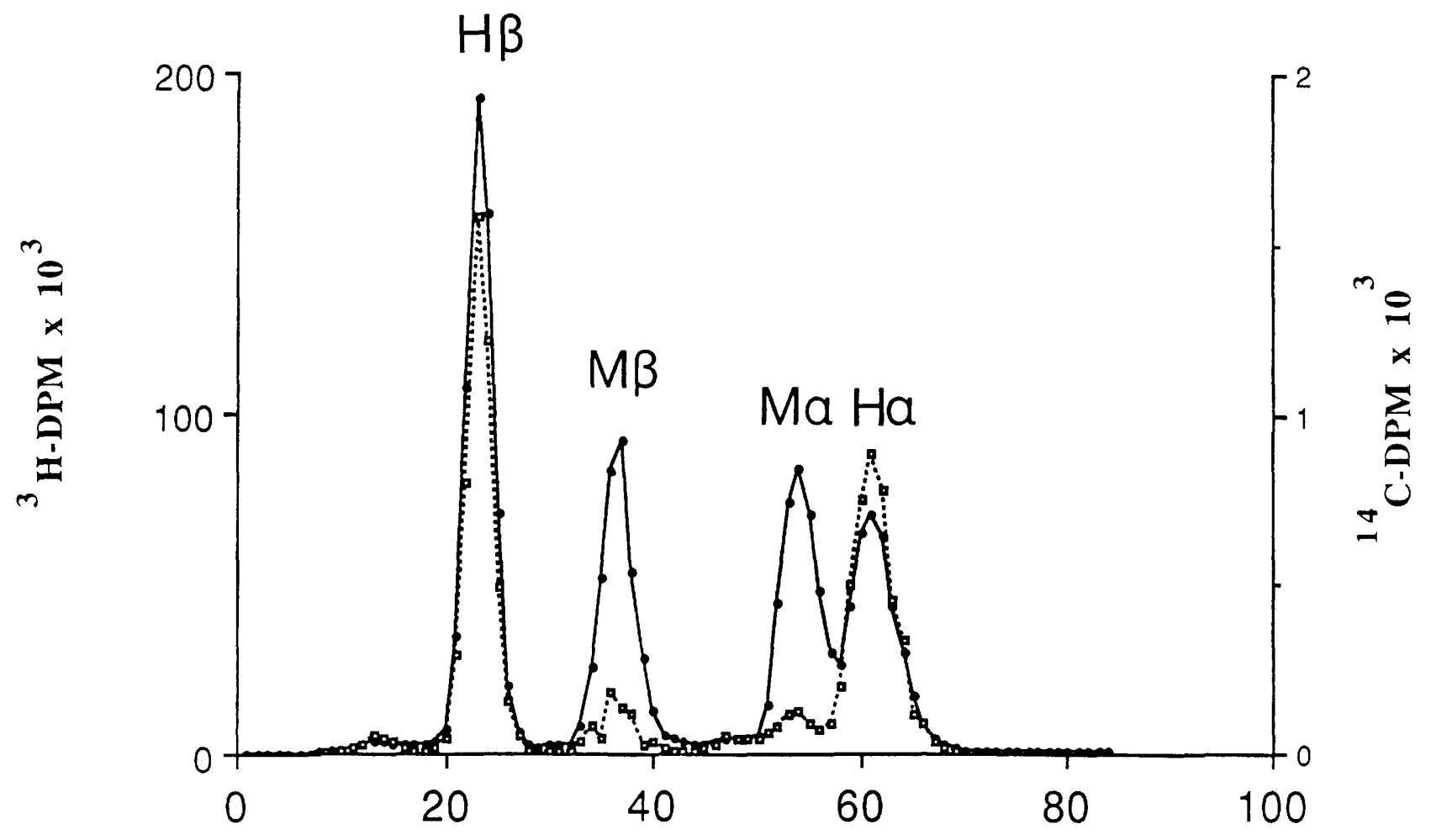

\section{Fraction number}

Figure 7. Metabolic labeling analysis of globin chain synthesis in $\alpha / \beta$ transgenic mouse 10 . Peripheral blood reticulocytes of $\alpha \beta$ transgenic mouse line 10 were used for metabolic labeling with $\left[{ }^{3} \mathrm{H}\right]$ leucine. Globin chains were prepared and mixed with ${ }^{14} \mathrm{C}-\mathrm{labeled}$ adult human globin chains. The globin mixture was subjected to chromatography on carboxymethyl cellulose, and column fractions were counted for ${ }^{3} \mathrm{H}$ and ${ }^{14} \mathrm{C}$.

sickle cell anemia of $\alpha$-thalassemia, often found to be a mitigating combination in the human disease.

\section{Methods \\ Constructs}

Constructs were as described in Figure 1 ; plasmids and cosmids were propagated in $\mathrm{DH} 5 \alpha$.

\section{Microinjection and identification of transgenic mice}

Plasmid fragments were purified by electroelution from agarose gels, and cosmid Sall fragments were recovered from $\mathrm{NaCl}$ gradients (Maniatis et al. 1982). DNA was injected at a concentration of $1 \mu \mathrm{g} / \mathrm{ml}$ into the pronuclei of $\left(\mathrm{C} 57 \mathrm{BL} \times \mathrm{CBA} / \mathrm{F}_{1}\right.$ fertilized eggs (Hogan et al. 1986). Injected eggs were transferred the same day to day- 0.5 pseudopregnant $F_{1}$ foster mothers. Embryos were analyzed at 12.5 and 13.5 days for $\alpha \theta$ constructs, and live mice were obtained for $\beta \alpha \theta$. Embryos and pups were analyzed for the presence of the injected fragment by Southern blot analysis of placental and tail DNA, respectively (Southern 1975). Probes used were a $0.75-\mathrm{kb}$ BstEII fragment for human $\alpha$-globin, a 0.9-kb BamHI-EcoRI fragment for human $\beta$-globin, a $1.2-\mathrm{kb}$ ApaI fragment from Thy-1.2 for copy determination, and a 3.3$\mathrm{kb} E$ coRI fragment from the $\alpha$-minilocus construct for end fragment analysis. Copy numbers were determined using densitometry of a range of autoradiographic exposures from at least two experiments.

\section{Preparation of RNA}

Tissues were homogenized in $6 \mathrm{M}$ urea and $3 \mathrm{M} \mathrm{LiCl}$ for $60 \mathrm{sec}$ and sonicated for $120 \mathrm{sec}$. After overnight precipitation at $4^{\circ} \mathrm{C}$, RNA was collected by centrifugation at $10,000 \mathrm{rpm}$ and $4^{\circ} \mathrm{C}$ for $30 \mathrm{~min}$ (Auffray and Rougeon 1980). Pellets were washed in the same solution, dissolved in $10 \mathrm{~mm}$ Tris- $\mathrm{HCl}(\mathrm{pH} 7.5)$ and $0.5 \%$ SDS and phenol/chloroform-extracted and ethanol-precipitated. RNA was dissolved in $10 \mathrm{~mm}$ Tris/1 mM EDTA.

\section{S1 nuclease analysis}

Globin RNA was assayed by nuclease S1 analysis (Berk and Sharp 1977; Weaver and Weissman 1979). Probes were end-labeled using T4 polynucleotide kinase (mouse $\alpha$, mouse $\beta$, and human $\beta$ ) or reverse transcriptase (human $\alpha$ ), and specific activities were estimated by Cerenkov counting. Labeled probe (10 $\mathrm{ng}$ ) was hybridized to total RNA in $20 \mu$ l of $40 \mathrm{mM}$ PIPES (pH 6.4 ), $400 \mathrm{~mm} \mathrm{NaCl}, 1 \mathrm{~mm}$ EDTA, and $80 \%$ (recrystallized) formamide overnight at $52^{\circ} \mathrm{C}$ ( $\beta$ probes) or $55^{\circ} \mathrm{C}$ ( $\alpha$ probes). Samples were digested for $2.5 \mathrm{hr}$ at $25^{\circ} \mathrm{C}$ with 100 units of S1 nuclease in $250 \mu \mathrm{l}$ of $200 \mathrm{~mm} \mathrm{NaCl}, 30 \mathrm{~mm} \mathrm{NaO}$ acetate (pH 4.5), and $2 \mathrm{~mm}$ $\mathrm{ZnSO}_{4}$. The DNA protected from S1 digestion was ethanol-precipitated and electrophoresed on $6 \%$ urea/polyacrylamide gels.

\section{Isoelectric focusing}

Total native proteins were isolated from $100 \mu \mathrm{l}$ of mouse blood by lysis in $250 \mathrm{~mm}$ sucrose, $1 \%$ aprotinin, and $1 \mathrm{mM}$ PMSF on ice, and concentrations were determined by $\mathrm{OD}_{415}$. Equal amounts of protein were loaded onto a $5 \%$ native acrylamide 
gel and focused over a 2-hr period. Ampholines in the range $\mathrm{pH}$ 7.0-9.0 and pH 3.5-10 (5:1) were used (LKB 2117 Multiphore system manuall.

\section{Acknowledgments}

We are grateful to Dr. Tony Magee for his help and advice with isoelectric focusing, to Sue Saunders for the electrophoretic analysis of hemoglobin, to David Ropers for the photographs, and to Cora $\mathrm{O}^{\prime}$ Carroll for typing this manuscript. This work was supported by the Medical Research Council (UK).

\section{References}

Auffray, C. and F. Rougeon. 1980. Purification of mouse immunoglobulin heavy-chain messenger RNAs from total myeloma tumour RNA. Eur. I. Biochem. 107: 303-314.

Berk, A.J. and P.A. Sharp. 1977. Sizing and mapping of early adenovirus mRNAs by gel electrophoresis of S1 endonculease digested hybrids. Cell 12: 721-732.

Blom van Assendelft, M., O. Hanscombe, F. Grosveld, and D.R. Greaves. 1989. The $\beta$-globin dominant control region activates homologous and heterologous promoters in a tissuespecific manner. Cell 56: 969-977.

Charnay, P., R. Treisman, P. Mellon, M. Chao, R. Axel, and T. Maniatis. 1984. Differences in human $\alpha$ - and $\beta$-globin gene expression in mouse erythroleukemia cells: The role of intragenic sequences. 38: 251-263.

Clegg, J.B., D.J. Weatherall, S. Na-Nakorn and P. Wasi. 1968. Haemoglobin synthesis in $\beta$-thalassemia. Nature 220: $664-$ 668.

Curtin, P., M. Pirastu, Y.W. Kan, J. Gobert-Jones, A. Stephens, and $H$. Lehmann. 1985. A distant gene deletion affects $\beta$ globin gene function in an atypical $\gamma / \delta / \beta$-thalassaemia. $J$. Clin. Invest. 76: 1554-1558.

Driscoll, C. 1989. In T.M. Ryan, R.R. Behringer, N.C. Martin, T.M. Townes, R.D. Palmiter, and R.L. Brinster. 1989. A single erythroid-specific DNase I super-hypersensitive site activates high levels of human $\beta$-globin gene expression in transgenic mice. Genes Dev. 3: 314-323.

Forrester, W.C., S. Takegawa, T. Papayannopoulou, G. Stamatoyannopoulos, and M. Groudin. 1987. Evidence for a locus activating region: The formation of developmentally stable hypersensitive sites in globin expressing hybrids. Nucleic Acids Res. 15: 10159-10177.

Greaves, D.R., F.D. Wilson, G. Lang, and D. Kioussis. 1989. Human CD2 3'-flanking sequences confer high-level, $T$ cellspecific, position-independent gene expression in transgenic mice. Cell 56: 979-986.

Grosveld, F., M. Blom van Assendelft, D.R. Greaves, and G. Kollias. 1987. Position-independent, high-level expression of the human $\beta$-globin gene in transgenic mice. Cell 51: 975-985.

Hogan, B., F. Costantini, and E. Lacy. 1986. Manipulating the mouse embryo. A laboratory manual. Cold Spring Harbor Laboratory, Cold Spring Harbor, New York.

Kioussis, D., E. Vanin, T. deLange, R.A. Flavell, and F.G. Grosveld. 1983. $\beta$-Globin gene inactivation by DNA translocation in $\gamma / \beta$-thalassaemia. Nature 306: 662-666.

Leung, S-O., N.J. Proudfoot, and E. Whitelaw. 1987. The gene for $\theta$-globin is transcribed in human fetal erythroid tissues. Nature 329: $551-554$.

Maniatis, T., E.F. Fritsch, and J. Sambrook. 1982. Molecular cloning: A laboratory manual. Cold Spring Harbor Laboratory, Cold Spring Harbor, New York.

Maniatis, T. E.F. Fritsch, J. Lauer, and R.M. Lawn. 1981. Molec- ular genetics of human hemoglobins. Annu. Rev. Genet. 14: 145-178.

Marks, J., J.-P. Shaw, and C.-K.J. Shen. 1986. Sequence organization and genomic complexity of primate $\theta 1$ globin gene, a novel $\alpha$-globin-like gene. Nature 321: 785-788.

Martinell, J., J.B. Whitney III, R.A. Popp, L.B. Russell, and W.F. Anderson. 1981. Three mouse models of human thalassemia. Proc. Natl. Acad. Sci. 78: 5056-5060.

Nicholls, R.D., N. Fischel-Ghodsian, and D.R. Higgs. 1987. Recombination at the human $\alpha$-globin gene cluster: Sequence features and topological constraints. Cell 49: 369-378.

Ryan, T.M., R.R. Behringer, T.M. Townes, R.D. Palmiter, and R.L. Brinster. 1989. High-level erythroid expression of human $\alpha$-globin genes in transgenic mice. Proc. Natl. Acad. Sci. 86: 37-41.

Schechter, A.N., C.T. Noguchi, and G.P. Rodgers. 1987. In The Molecular Basis of Blood Diseases (ed. G. Stamatoyannopoulos, A.W. Nienhuis, P. Leder, and P.W. Majerus), pp. 179-218. W.B. Saunders, Philadelphia.

Serjeant, G.R. 1985. Sickle cell disease. Oxford University Press, Oxford.

Shaw, J.-P., J. Marks, and C.-K.J. Shen. 1987. Evidence that the recently discovered $\theta 1$-globin gene is functional in higher primates. Nature 326: 717-720.

Skow, L.C., B.A. Burkhart, F.M. Johnson, R.A. Popp, D.M. Popp, S.Z. Goldberg, W.F. Anderson, L.B. Barnett, and S.E. Lewis. 1983. A mouse model for $\beta$-thalassemia. Cell 34: 10431052.

Southern, E.M. 1975. Detection of specific sequences among DNA fragments separated by gel electrophoresis. $J$. Mol. Biol. 98: 503-517.

Talbot, D., P. Collis, M. Antoniou, M. Vidal, F. Grosveld, and D.R. Greaves. 1989. A dominant control region from the human $\beta$-globin locus conferring integration site-independent gene expression. Nature 338: 352-353.

Taramelli, R., D. Kioussis, E. Vanin, K. Bartram, J. Groffen, J. Hurst, and F. Grosveld. 1986. $\gamma / \delta / \beta$-Thalassaemias 1 and 2 are the result of a $100 \mathrm{kbp}$ deletion in the human $\beta$-globin cluster. Nucleic Acids Res. 14: 7017-7029.

Treisman, R., M.R. Green, and T. Maniatis. 1983. Cis and trans activation of globin gene transcription in transient assays. Proc. Natl. Acad. Sci. 80: 7428-7432.

Tuan, D., W. Solomon, L.S. Qiliang, and M.L. Irving. 1985. The ' $\beta$-like-globin' gene domain in human erythroid cells. Proc. Natl. Acad. Sci. 32: 6384-6388.

van der Ploeg, L.H.T., A. Konings, M. Oort, D. Roos, L. Bernini, and R.A. Flavell. 1980. $\gamma / \beta$-Thalassaemia: Deletion of the $\gamma$ and $\delta$-genes influences $\beta$-globin gene expression in man. $\mathrm{Na}$ ture 283: 637-642.

Weatherall, D.J. and J.B. Clegg. 1981. The thalassaemia syndromes. Blackwell Scientific Publications, Boston.

Weaver, R. and C. Weissmann. 1979. Mapping of RNA by a modification of the Berk-Sharp procedure; the $5^{\prime}$ termini of 15S $\beta$-globin mRNA precursor and 10S $\beta$-globin mRNA have identical map co-ordinates. Nucleic Acids Res. 6: $1175-1192$.

Whitelaw, E., P. Hogben, O. Hanscombe, and N.J. Proudfoot. 1989. Transcriptional promiscuity of the human $\alpha$-globin gene. Mol. Cell. Biol. 9: 241-251. 


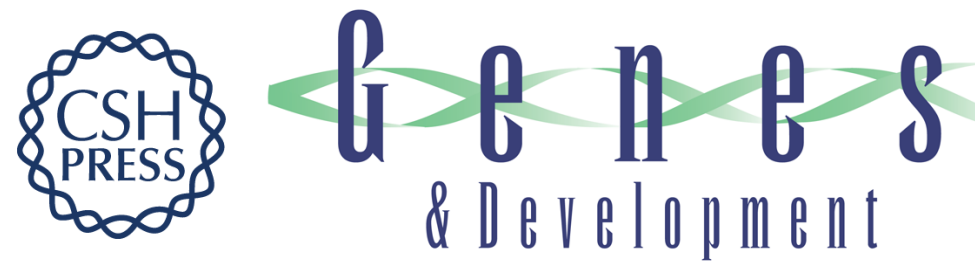

\section{High-level, erythroid-specific expression of the human alpha-globin gene in transgenic mice and the production of human hemoglobin in murine erythrocytes.}

O Hanscombe, M Vidal, J Kaeda, et al.

Genes Dev. 1989, 3:

Access the most recent version at doi:10.1101/gad.3.10.1572

References This article cites 26 articles, 5 of which can be accessed free at:

http://genesdev.cshlp.org/content/3/10/1572.full.html\#ref-list-1

License

Email Alerting

Service

Receive free email alerts when new articles cite this article - sign up in the box at the top right corner of the article or click here.

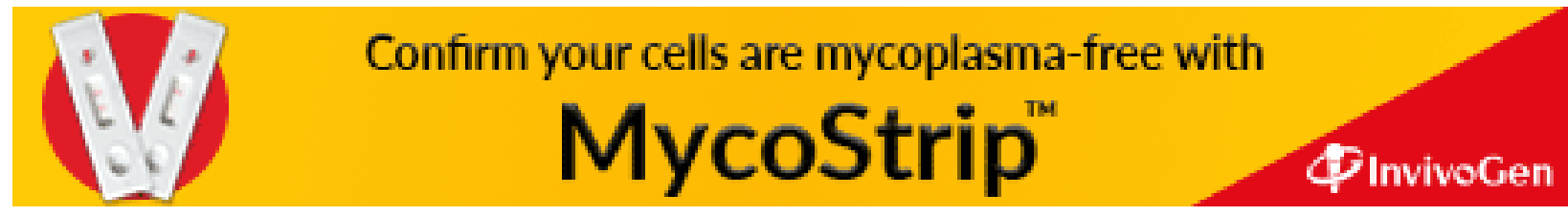

